\title{
Designs for Development of Bra Tops for the New Senior Generation
}

\author{
Hosun Lim ${ }^{1)}$ and Hakyung Cho ${ }^{2) \dagger}$ \\ ${ }^{1)}$ Dept. of R\&D, i-Fashion Biz Center, Seongnam-si, Korea \\ ${ }^{2)}$ Dept. of R\&D, LUCIS Co., Ltd., Seoul, Korea
}

\begin{abstract}
Due to recent changes in increased life expectancy, economic power and social development, the new senior generation (focusing on people in their fifties) represents a new market power with strong competitiveness. The new senior generation is the generation after the baby boomers, with characteristics that include a high-level of education, increased income, a high-level of consumption, increased assets, self-fulfillment desires and individuality. Demands in the senior fashion industry are expected to gradually increase and the underwear industry that targets the new senior generation is expected to grow rapidly. These demands will require product development for the new senior generation based on emotional and socio-cultural characteristics. The current new senior underwear market is under the process of R\&D with a focus on body shape changes; however, there are limited studies on emotional and socio-cultural approaches. This study formulates a basic design plan for different age groups based on an analysis of the situation of bra wear (current inconveniences, demand and needs) by women in their fifties and over. Subsequently, a functional active bra top that considers activity and comfort was proposed for women in their fifties, an all-in-one foundation bra top that shapes the body was proposed for women in their sixties, and comfort bra tops that are comfortable and easy to put on and take off were proposed for women in their seventies and over.
\end{abstract}

Key words: senior generation, bra tops, comfortable, functional, underwear

\section{Introduction}

The world is at the start of an aging society due to increased average life span and standard of living thanks to economic, social and medical developments. Advanced countries are already aging societies, with the population aged 65 or above taking up more than $7 \%$ of the total population, and Korea also passed the $7 \%$ mark in 2000. Population scholars predict that we will live in an aging society where $14 \%$ of the population are elderly by 2021 ("Aging society", n.d.). In an aging society, the senior generation is recognized as a generation with a high economic participation rate and purchase power, unlike existing generations, and there is a need for active counteraction to the demands of aging consumers(Kang, 2010). Amid changes in the population structure, the consumption market is expanding, focusing on the elderly and women, and an expansion of the women's body shaping underwear market is predicted(Attention-promising market in demographic change, 2012). The new senior generation, focusing on baby boomers, is especially active in society unlike past generations, and are divided as a new type of elderly generation that yearns for a comfortable and easy life and is highly interested in enjoying healthy senior

$\dagger$ Corresponding author; Hakyung Cho

Tel. +82-2-368-3864, Fax. +82-2-368-3828

E-mail: instyle1010@naver.com

This paper was presented at 2013 Spring Conference of the Society of Fashion and Textile Industry.
years(Lee \& Chun, 2012). The generation of elders aged 50 and above, categorized as the new senior generation, is a socially and economically stable generation, and not only places importance on changes in body shape, but also on elements like design and color that reflect their psychology and lifestyle, etc.(Cha, 2008). Product development for this generation requires multi-dimensional approaches from the socio-cultural and emotional aspects.

The functional underwear market is becoming active recently, focusing on the overseas clothing market, and the demand for elderly underwear is expected to grow in the domestic market, too(Lee $\&$ Chun, 2012). However, analysis of underwear related demands are currently limited to research and development with younger people as subjects, and there is a lack of studies that analyze the situation of wear by seniors and their needs, and research product development that reflects such analysis. Therefore, this study aimed to present designs for bra tops for the new senior generation based on analysis of bra wear and needs of women in their fifties and above, who are defined as the new senior generation, aimed for development of highly functional bra tops that consider the characteristics and needs of the particular generation.

\section{Theoretical background}

\subsection{New senior generation}

Based on various views on the new elderly generation since peo- 
ple in their fifties with a high level of education and economic power have joined the senior generation since the 2000s, the new senior generation is defined as the baby boomer generation that has grown old -- i.e. those aged 50 or above who were born when World War II ended(Kang, 2010; Lee \& Chun, 2012).

The new senior generation, focusing on young baby boomer senior citizens, have independent and confident consumption behavior. They are also not only recognized as smart consumers as they have been the leaders of economic activities in industrial society(Kim, 2011), but they can also be seen as the generation that has an independent and active role, unlike past silver generations. In addition, with improved awareness and economic level leading to improved levels of demands and expectations for higher quality of life, the new senior generation is participating more actively in society and their interest in clothing is also increasing(Kang, 2010). The new senior generation is a cautious and mature consumer group that plans purchases and makes their own purchases. They place importance on dignity, and want to look young but also have aesthetic desires and Western values, making them different from the existing silver generation. They are expected to surface as an important new consumer group in the future.

\subsection{The new senior generation underwear market}

The new senior generation are intelligent and have a sophisticated economic mind, with interest in social issues. Clothing stores for seniors were first introduced in Korea in the 1990s, focusing on department stores, and the importance of clothing products that consider psychological and physical characteristics have been presented(Chung, 2004). The market scale of the silver clothing industry was 11,412 billion won in 2010 , and is expected to grow to 3303 billion won by 2020 (Kim, 2010). The underwear market, based on the expansion of the new senior generation clothing industry, is a sensitive industry through multi-dimensional approaches considering emotional and physical characteristics, and is expected to be a new opportunity for the underwear market in the face of an aging society(Cha, 2008). In Japan, highly functional bra brands considering matters such as the movement of joints and walking motions of senior women are rapidly increasing by $50-60 \%$ each year, and the purchase amount of underwear by married women between the ages of 55 and 64 is increasing so much that it is now around 60$70 \%$ of the amount purchased by married women in their twenties and forties(Park, 2003). Expansions are gradually being made to the senior underwear market in Korea, too, through efforts such as developing bodywear that applies ergonomic patterns that reflect trends for women in their fifties and above. Importance of design elements such as supporting ease of putting on, application of physical changes, clear relaying of information and skin protection, and aesthetics is especially being highlighted for underwear design (Cha, 2008), and the market is expected to expand through development of clothing products for the new senior generation considering elements such as emotional and physical characteristics.

\section{Research method}

\subsection{Research method}

A survey was conducted from February 12, 2013 to March 15, 2013, to analyze the situation of bra wear and product needs and extract a basic design plan for bra tops for different age groups, with the aim of planning bra top products for the new senior generation. The subjects were new senior generation women in their fifties and above. A total of 220 surveys were distributed. 27 statistically insignificant surveys were excluded, and a total or 193 significant results were used for analysis.

SPSS 18.0 and Excel were used for statistical analysis. Frequency analysis and cross tabulation were applied, and a basic design plan for bra tops for seniors was presented based on the results.

\subsection{Survey structure}

Surveys in preceding studies(Choi, 1995; Kang, 2010; Kim, 2006; Kim, 2011) were referred to for the design plan of highly functional bra tops for the new senior generation considering bra wear and needs. 8 questions on current bra wear, 25 questions on inconveniences of bra wear, 20 questions on demands and needs, and 4 demographic questions were presented.

\subsection{Design extraction}

Based on the survey results on current bra wear, considerations and needs, a basic design plan for bra tops for different age groups was extracted and presented.

\section{Results}

\subsection{Demographic characteristics}

The demographic characteristics of the new senior generation women who participated in the study are as follows. $51 \%$ of the women were aged $50 \sim 54$, and $72 \%$ said they considered themselves to be younger than their actual age. $79 \%$ of women between the ages of 50 and $59,71 \%$ of women between the ages of 60 and 69 , and $65 \%$ of women aged 70 and over were found to consider themselves to be younger than their actual age. The biggest difference between actual age and cognitive age was found in the 5059 age group, and the difference decreased as the age grew higher. $7.5 \%(n=11)$ of women in the 50-59 age group said they felt like 
they were $30-39$ years old, and $11 \%(n=5)$ of women in the $60-69$ age group said they felt like they were 40-49 years old. Most of the subjects (52\%) lived in Seoul, and 76\% said they earned their own income.

\subsection{Actual wearing state according to age}

4.2.1. Bra wear according to age

As a result of comparative analysis of bra wear according to age, there were no significance differences. Most ages were found to wear just a bra.

\subsubsection{Reason for wearing bra according to age}

There were significant differences in reason for wearing a bra according to age. Those aged 50 59 said the biggest reason for wearing a bra was to prevent exposure and movement, and those aged 60 and above said the biggest reason was to prevent sagging.

\subsubsection{Place of bra purchase according to age}

There were no significant differences in place of bra purchase according to age. Most made their purchases at underwear stores or large discount stores, in order of frequency.

Table 1. Demographic characteristics

\begin{tabular}{|c|c|c|c|}
\hline \multicolumn{2}{|c|}{ Demographic elements } & $\mathrm{N}$ & $\%$ \\
\hline \multirow{5}{*}{ Age } & $50 \sim 54$ & 98 & 51 \\
\hline & $55 \sim 59$ & 42 & 22 \\
\hline & $60 \sim 64$ & 26 & 13 \\
\hline & $65 \sim 69$ & 9 & 5 \\
\hline & 70 or above & 18 & 9 \\
\hline \multicolumn{2}{|c|}{ Total } & 193 & 100 \\
\hline \multirow{5}{*}{ Age perception } & $30 \sim 39$ & 11 & 6 \\
\hline & $40 \sim 49$ & 83 & 43 \\
\hline & $50 \sim 59$ & 72 & 37 \\
\hline & $60 \sim 69$ & 20 & 10 \\
\hline & 70 or above & 13 & 7 \\
\hline \multicolumn{2}{|c|}{ Total } & 193 & 100 \\
\hline \multirow{3}{*}{ Place of residence } & Seoul & 101 & 52 \\
\hline & Goyang & 63 & 33 \\
\hline & Other & 29 & 15 \\
\hline \multicolumn{2}{|c|}{ Total } & 193 & 100 \\
\hline \multirow{5}{*}{ Income } & Pension & 11 & 6 \\
\hline & Earned income & 147 & 76 \\
\hline & Income through assets & 15 & 8 \\
\hline & Allowance & 14 & 7 \\
\hline & Other & 6 & 3 \\
\hline \multicolumn{2}{|c|}{ Total } & 193 & 100 \\
\hline
\end{tabular}

Table 2. Bra wear according to age

\begin{tabular}{ccccc}
\hline & $50 \sim 59$ & $60 \sim 64$ & 70 or above & Total \\
\hline $\begin{array}{c}\text { Sleeveless top } \\
\text { over a bra }\end{array}$ & 51 & 7 & 2 & 60 \\
Short sleeved top & 18 & $(20 \%)$ & $(11 \%)$ & $(31 \%)$ \\
over a bra & $(13 \%)$ & $(20 \%)$ & $(28 \%)$ & $(16 \%)$ \\
Only bra & 71 & 21 & 11 & 103 \\
& $(51 \%)$ & $(60 \%)$ & $(61 \%)$ & $(53 \%)$ \\
\hline Total & 140 & 35 & 18 & 193 \\
& $(100 \%)$ & $(100 \%)$ & $(100 \%)$ & $(100 \%)$ \\
\hline
\end{tabular}

Table 3. Reason for wearing bra according to age

\begin{tabular}{ccccc}
\hline & $50 \sim 59$ & $60 \sim 69$ & 70 or above & Total \\
\hline Habit & 22 & 8 & 0 & 30 \\
& $(16 \%)$ & $(23 \%)$ & $(0 \%)$ & $(16 \%)$ \\
To prevent & 32 & 4 & 3 & 39 \\
movement & $(23 \%)$ & $(11 \%)$ & $(17 \%)$ & $(20 \%)$ \\
To prevent & 56 & 7 & 2 & 65 \\
exposure & $(40 \%)$ & $(20 \%)$ & $(11 \%)$ & $(34 \%)$ \\
To prevent & 27 & 14 & 11 & 52 \\
sagging & $(19 \%)$ & $(40 \%$ & $(61 \%)$ & $(27 \%)$ \\
& 3 & 2 & 2 & 7 \\
Other & $(2 \%)$ & $(6) \%$ & $(11 \%)$ & $(4 \%)$ \\
\hline \multirow{2}{*}{ Total } & 140 & 35 & 18 & 193 \\
& $(100 \%)$ & $(100 \%)$ & $(100 \%)$ & $(100 \%)$ \\
\hline
\end{tabular}

4.2.4. Inconveniences when wearing bra according to age

As a result of cross tabulation of inconveniences when wearing a bra according to age, there were significant differences according to age for the following elements - breast comfort, breast pressure, shoulder strap slipping, shoulder strap pressure and bra side pressure. Those in the 50 54 age groups found fit, wearing and taking off, breast comfort, shoulder strap slipping, discomfort from wire and sweat the most inconvenient, and those in the 55 59 age group

Table 4. Place of bra purchase according to age $\mathrm{N}(\%)$

\begin{tabular}{|c|c|c|c|c|}
\hline & $50 \sim 59$ & $60 \sim 69$ & 70 or above & Total \\
\hline Department store & $\begin{array}{c}14 \\
(10)\end{array}$ & $\begin{array}{c}3 \\
(9)\end{array}$ & $\begin{array}{c}0 \\
(0)\end{array}$ & $\begin{array}{l}17 \\
(9)\end{array}$ \\
\hline Large discount store & $\begin{array}{c}40 \\
(29)\end{array}$ & $\begin{array}{c}10 \\
(29)\end{array}$ & $\begin{array}{c}7 \\
(39)\end{array}$ & $\begin{array}{c}57 \\
(30)\end{array}$ \\
\hline Underwear store & $\begin{array}{c}67 \\
(48)\end{array}$ & $\begin{array}{c}18 \\
(51)\end{array}$ & $\begin{array}{c}11 \\
(61)\end{array}$ & $\begin{array}{c}96 \\
(50)\end{array}$ \\
\hline Imported goods store & $\begin{array}{c}1 \\
(1)\end{array}$ & $\begin{array}{c}1 \\
(3)\end{array}$ & $\begin{array}{c}0 \\
(0)\end{array}$ & $\begin{array}{c}2 \\
(1)\end{array}$ \\
\hline Internet shopping & $\begin{array}{c}9 \\
(6)\end{array}$ & $\begin{array}{c}0 \\
(0)\end{array}$ & $\begin{array}{c}0 \\
(0)\end{array}$ & $\begin{array}{c}9 \\
(5)\end{array}$ \\
\hline TV home shopping & $\begin{array}{c}9 \\
(6)\end{array}$ & $\begin{array}{c}3 \\
(9)\end{array}$ & $\begin{array}{c}0 \\
(0)\end{array}$ & $\begin{array}{l}12 \\
(6)\end{array}$ \\
\hline Total & $\begin{array}{c}140 \\
(100)\end{array}$ & $\begin{array}{c}35 \\
(100)\end{array}$ & $\begin{array}{c}18 \\
(100)\end{array}$ & $\begin{array}{c}193 \\
(100)\end{array}$ \\
\hline
\end{tabular}


Table 5. Inconveniences when wearing bra according to age

\begin{tabular}{lccccccc}
\hline & $50 \sim 54$ & $55 \sim 59$ & $60-64$ & $65 \sim 69$ & $\begin{array}{c}70 \text { or } \\
\text { above }\end{array}$ & average & $\chi^{2}$ \\
\hline Fit & 3.1 & 3.0 & 2.8 & 2.5 & 2.5 & 2.78 & - \\
Uncomfortable & 3.0 & 3.1 & 2.8 & 2.8 & 3.4 & 3.02 & $.001^{* *}$ \\
wearing and taking off & & & & & & & \\
Cup fit & 2.9 & 3.2 & 2.9 & 2.8 & 2.6 & 2.88 & - \\
Bad shape & 2.8 & 3.0 & 2.8 & 2.9 & 2.8 & 2.86 & - \\
Breast comfort & 3.1 & 3.5 & 3.0 & 2.6 & 2.8 & 3.00 & $.023^{*}$ \\
Breast pressure & 2.5 & 2.5 & 2.4 & 2.5 & 3.2 & 2.62 & $.015^{*}$ \\
Shoulder strap slipping & 3.4 & 3.4 & 3.3 & 2.9 & 2.4 & 3.08 & $.003^{*}$ \\
Shoulder strap & 2.5 & 2.5 & 2.8 & 2.3 & 3.2 & 2.66 & $.025^{*}$ \\
pressure & & & & & & & \\
Side pressure & 2.7 & 2.7 & 3.1 & 2.8 & 2.7 & 2.80 & $.016^{*}$ \\
Wire discomfort & 3.3 & 3.4 & 3.0 & 3.2 & 4.4 & 3.46 & - \\
Breast movement & 2.2 & 2.4 & 2.4 & 2.3 & 2.4 & 2.34 & - \\
Sweat & 3.4 & 3.3 & 3.8 & 2.6 & 3.3 & 3.28 & $.018^{*}$ \\
Average & 2.91 & 3.00 & 2.92 & 2.68 & 2.98 & 2.90 & - \\
\hline$* p<.05, * * p<.01$ & & & & & & & \\
\hline
\end{tabular}

found fit, wearing and taking of discomfort due to back opening, cup fit, breast comfort, shoulder strap slipping and sweat the most inconvenient. Those in the 60 64 age group found breast comfort and side pressure to be the most inconvenient, and those in the 70 and above age group found breast pressure, shoulder strap pressure, wire discomfort and uncomfortable wearing and taking off to be the most inconvenient. All the ages found wires to be uncomfortable, but those in their sixties found it to be less of a problem, and those aged 70 and above found wires to be the most uncomfortable.

4.2.5. Points of consideration when purchasing bra according to age As a result of analysis of multiple answers on considerations when purchasing bra according to age, those in the 50 54 age group were found to consider comfort, design and quality the most, and those in the 55 59 age group were found to consider comfort, price and quality the most, in order of most important. Those in the 60 64 age group found comfort the most important, and also considered price and design when purchasing a bra, in order of importance. Those in the 65 69 page group was found to place similar importance on price, quality, design, material and color. Those aged 70 and above placed most importance on price, followed by comfort, quality and material.

\subsubsection{Areas of pressure when wearing a bra}

There were no significant differences different age groups and method of bra wear for areas of pressure when wearing a bra. The biggest pressure was found to be under the breasts and the sides whether
Table 6. Points of consideration when purchasing bra according to age

\begin{tabular}{|c|c|c|c|c|c|c|}
\hline & $50 \sim 54$ & $55 \sim 59$ & $60 \sim 64$ & $65 \sim 69$ & 70 or above & Total \\
\hline Fit & $\begin{array}{c}26 \\
(10)\end{array}$ & $\begin{array}{c}14 \\
(11)\end{array}$ & $\begin{array}{c}4 \\
(5)\end{array}$ & $\begin{array}{c}3 \\
(5)\end{array}$ & $\begin{array}{c}3 \\
(5)\end{array}$ & $\begin{array}{l}50 \\
(9)\end{array}$ \\
\hline Comfort & $\begin{array}{c}80 \\
(31)\end{array}$ & $\begin{array}{c}35 \\
(27)\end{array}$ & $\begin{array}{c}16 \\
(21)\end{array}$ & $\begin{array}{c}8 \\
(13)\end{array}$ & $\begin{array}{c}9 \\
(14)\end{array}$ & $\begin{array}{l}148 \\
(25)\end{array}$ \\
\hline Design & $\begin{array}{c}31 \\
(12)\end{array}$ & $\begin{array}{l}12 \\
(9)\end{array}$ & $\begin{array}{c}11 \\
(14)\end{array}$ & $\begin{array}{c}9 \\
(14)\end{array}$ & $\begin{array}{c}8 \\
(13)\end{array}$ & $\begin{array}{c}71 \\
(12)\end{array}$ \\
\hline Quality & $\begin{array}{c}31 \\
(12)\end{array}$ & $\begin{array}{c}19 \\
(15)\end{array}$ & $\begin{array}{c}8 \\
(11)\end{array}$ & $\begin{array}{c}10 \\
(16)\end{array}$ & $\begin{array}{c}9 \\
(14)\end{array}$ & $\begin{array}{c}77 \\
(13)\end{array}$ \\
\hline Material & $\begin{array}{l}25 \\
(10)\end{array}$ & $\begin{array}{l}11 \\
(9)\end{array}$ & $\begin{array}{c}10 \\
(13)\end{array}$ & $\begin{array}{c}9 \\
(14)\end{array}$ & $\begin{array}{c}9 \\
(14)\end{array}$ & $\begin{array}{c}64 \\
(11)\end{array}$ \\
\hline Color & $\begin{array}{l}19 \\
(7)\end{array}$ & $\begin{array}{c}6 \\
(5)\end{array}$ & $\begin{array}{c}9 \\
(12)\end{array}$ & $\begin{array}{c}9 \\
(14)\end{array}$ & $\begin{array}{c}8 \\
(13)\end{array}$ & $\begin{array}{l}51 \\
(9)\end{array}$ \\
\hline Price & $\begin{array}{c}26 \\
(10)\end{array}$ & $\begin{array}{c}25 \\
(19)\end{array}$ & $\begin{array}{c}13 \\
(17)\end{array}$ & $\begin{array}{c}11 \\
(17)\end{array}$ & $\begin{array}{c}14 \\
(22)\end{array}$ & $\begin{array}{c}89 \\
(15)\end{array}$ \\
\hline Brand & $\begin{array}{l}11 \\
(4)\end{array}$ & $\begin{array}{c}4 \\
(3)\end{array}$ & $\begin{array}{c}1 \\
(1)\end{array}$ & $\begin{array}{c}0 \\
(0)\end{array}$ & $\begin{array}{c}0 \\
(0)\end{array}$ & $\begin{array}{l}16 \\
(3)\end{array}$ \\
\hline $\begin{array}{l}\text { Easy } \\
\text { cleaning }\end{array}$ & $\begin{array}{c}5 \\
(2)\end{array}$ & $\begin{array}{c}3 \\
(2)\end{array}$ & $\begin{array}{c}3 \\
(4)\end{array}$ & $\begin{array}{c}3 \\
(5)\end{array}$ & $\begin{array}{c}3 \\
(5)\end{array}$ & $\begin{array}{l}17 \\
(3)\end{array}$ \\
\hline $\begin{array}{l}\text { After } \\
\text { service }\end{array}$ & $\begin{array}{c}0 \\
(0)\end{array}$ & $\begin{array}{c}0 \\
(0)\end{array}$ & $\begin{array}{c}1 \\
(1)\end{array}$ & $\begin{array}{c}1 \\
(2)\end{array}$ & $\begin{array}{c}1 \\
(2)\end{array}$ & $\begin{array}{c}3 \\
(1)\end{array}$ \\
\hline Total & $\begin{array}{c}254 \\
(100)\end{array}$ & $\begin{array}{c}129 \\
(100)\end{array}$ & $\begin{array}{c}76 \\
(100)\end{array}$ & $\begin{array}{c}63 \\
(100)\end{array}$ & $\begin{array}{c}64 \\
(100)\end{array}$ & $\begin{array}{c}586 \\
(100)\end{array}$ \\
\hline
\end{tabular}

or not there was a wire. In the case of a wire, the pressure was greater for areas other than the top of the breasts compared to no wire.

\subsection{Bra needs according to age}

\subsubsection{Desired cup shape according to age}

Bra cup needs according to age are as follows. As a result of cross tabulation according to age, there were significant results for comfortable cup, cup that holds breasts, cup that lifts breasts and cup that holds breasts, and the results are show in the table below.

Those in the 50 59 age group had a tendency to pursue bra cups that are comfortable and gather breasts together, and those in the 60 69 age group tended to pursue cups that gather breasts together, lift breasts and hold breasts, showing a greater needs for breast shaping than other age groups. Also, there were no significant results, but those aged 70 and above had a tendency to pursue cups without a wire, showing that they find wires more uncomfortable than other age groups. Those in the 60 64 age group were found to

Table 7. Areas of pressure when wearing a bra

\begin{tabular}{lcccc}
\hline & $\begin{array}{c}\text { Center of } \\
\text { breasts }\end{array}$ & $\begin{array}{c}\text { Under } \\
\text { breasts }\end{array}$ & $\begin{array}{c}\text { Top of } \\
\text { breasts }\end{array}$ & Sides of breasts \\
\hline No wire & 2.7 & 3.0 & 2.7 & 3.0 \\
Wire & 2.9 & 3.5 & 2.6 & 3.2 \\
Average & 2.8 & 3.25 & 2.65 & 3.1 \\
\hline
\end{tabular}


Table 8. Desired cup shape according to age

\begin{tabular}{|c|c|c|c|c|c|c|c|}
\hline \multirow[b]{2}{*}{ Comfortable up } & \multicolumn{4}{|c|}{$50 \sim 5455 \sim 5960 \sim 6465 \sim 69$} & \multirow{2}{*}{$\begin{array}{c}\begin{array}{c}70 \text { or } \\
\text { above }\end{array} \\
3.6\end{array}$} & \multirow{2}{*}{$\begin{array}{c}\text { average } \\
3.50\end{array}$} & \multirow{2}{*}{$\frac{\chi^{2}}{.003 *}$} \\
\hline & 3.6 & 3.7 & 3.2 & 3.4 & & & \\
\hline $\begin{array}{l}\text { Cup that brings } \\
\text { breasts together }\end{array}$ & 3.2 & 3.3 & 3.6 & 3.5 & 3.3 & 3.38 & $.012 *$ \\
\hline Cup that lifts breasts & 3.2 & 3.3 & 3.6 & 3.5 & 3.2 & 3.36 & $.001 * *$ \\
\hline $\begin{array}{l}\text { Cup that holds } \\
\text { breasts }\end{array}$ & 3.4 & 3.5 & 3.5 & 3.4 & 3.2 & 3.40 & $.001 * *$ \\
\hline No wire & 3.3 & 3.3 & 3.1 & 3.3 & 3.7 & 3.34 & - \\
\hline Wire & 3.2 & 3.3 & 3.4 & 3.2 & 3.1 & 3.24 & - \\
\hline Average & 3.32 & 3.40 & 3.40 & 3.38 & 3.35 & 3.37 & \\
\hline
\end{tabular}

prefer bras with wires. This results is considered to be related to the results that the 60 64 age group has a higher interest in figure shaping than other age groups.

\subsubsection{Specific reasons for pursuing bra according to age}

As a result of analyzing type of bra pursued according to age, those in the 50 59 age group had a highest preference for fixed trap, and also preferred easy wearing and taking off, and a bra top that covers the breasts as specific design elements. Those in the 60 69 age group was analyzed to prefer figure shaping, covering the breasts, and covering the stomach and back. Those in the 70 and above age group preferred no pressure, easy wearing and taking off, covering the breasts and a bra top form.

\subsubsection{Bra types pursued according to age}

As a result of analyzing type of bra pursued according to age, those in their fifties wanted functional bras that are comfortable and hold the breasts, those in their sixties wanted shaping bras that

Table 9. Specific reasons for pursuing bra according to age

\begin{tabular}{|c|c|c|c|c|c|c|c|}
\hline & $50 \sim 54$ & $55 \sim 59$ & $60 \sim 64$ & $65 \sim 697$ & or above & average & $\chi^{2}$ \\
\hline Fixed strap & 3.6 & 3.7 & 3.4 & 3.3 & 3.5 & 3.50 & $.026^{*}$ \\
\hline No pressure & 3.2 & 3.1 & 3.2 & 3.2 & 3.8 & 3.30 & $.032 *$ \\
\hline $\begin{array}{l}\text { Easy wearing } \\
\text { and taking off }\end{array}$ & 3.3 & 3.5 & 3.3 & 3.4 & 3.7 & 3.44 & - \\
\hline Figure shaping & 3.2 & 3.1 & 3.6 & 3.5 & 3.0 & 3.28 & $.012 *$ \\
\hline Some exposure & 2.8 & 3.0 & 3.2 & 3.0 & 2.9 & 2.98 & - \\
\hline $\begin{array}{l}\text { Covering } \\
\text { breasts }\end{array}$ & 3.3 & 3.2 & 3.0 & 3.1 & 3.5 & 3.22 & $.001 * *$ \\
\hline Bra top & 3.6 & 3.4 & 3.0 & 3.1 & 3.5 & 3.32 & $.018^{*}$ \\
\hline $\begin{array}{l}\text { Bra top that } \\
\text { protects back } \\
\text { and stomach }\end{array}$ & 3.1 & 2.9 & 3.5 & 3.5 & 3.0 & 3.20 & - \\
\hline Average & 3.26 & 3.24 & 3.27 & 3.26 & 3.36 & 3.28 & - \\
\hline
\end{tabular}

Table 10. Bra types pursued according to age $\mathrm{N}(\%)$

\begin{tabular}{lcccccc}
\hline & $50 \sim 54$ & $55 \sim 59$ & $60 \sim 64$ & $65 \sim 69$ & 70 or above & Total \\
\hline Comfortable & 31 & 12 & 5 & 3 & 10 & 61 \\
bra & $(32)$ & $(29)$ & $(19)$ & $(33)$ & $(56)$ & $(32)$ \\
Shaping bra & 19 & 10 & 12 & 4 & 3 & 48 \\
& $(19)$ & $(24)$ & $(46)$ & $(44)$ & $(17)$ & $(25)$ \\
Functional & 48 & 20 & 9 & 2 & 5 & 84 \\
bra & $(49)$ & $(48)$ & $(35)$ & $(22)$ & $(28)$ & $(44)$ \\
Total & 98 & 42 & 26 & 9 & 18 & 193 \\
& $(100)$ & $(100)$ & $(100)$ & $(100)$ & $(100)$ & $(100)$ \\
\hline
\end{tabular}

shape their figure, and those aged 70 and above had a high preference for comfortable bras that cover the breasts. This confirmed the analysis of bra shape needs.

\section{Conclusion}

This study aimed to propose functional bra top designs for the new senior generation aged 50 and above, based on the bra wear and needs analysis of different age groups.

As a result, those in their fifties were found to wear bras to prevent exposure and breast movement, and inconveniences were found to be bad fit, difficult wearing and taking off due to the bad cup fit, uncomfortable breasts, and slipping strap. Elements considered for purchase were comfort, price, design and quality, and they were found to have needs for a bra cup that is comfortable and holds the breasts, and fixed shoulder straps. Therefore, the bra top for the 50 59 age group was designed as a non-pressure active style bra top that has no wire and is guarantees comfort and free movement, but covers the breasts.

Those in the 60 64 age group was found to wear bras to prevent sagging and exposure, and because of habit. When making a purchase, they considered price, quality, design, material and color. In the 60 69 age group, their biggest inconveniences were breast comfort and pressure at the sides, and they had a tendency to pursue bra cups that hold the shape of the breasts. They also pursued forms that shaped the stomach and back, and had a greater need than other age groups for breast and figure shaping. Therefore, the bra top design plan for the $60 \sim 69$ age group was proposed as an allin-one foundation type that has no wire and is shape the breast, stomach and back.

Those aged 70 and above said they wore bras to prevent sagging, and major points of consideration were price, comfort, quality and material. They felt the most discomfort from pressure, wire and inconvenient wearing and taking off, and had a tendency to pursue cups without wires. The needs of those in their seventies and above were analyzed to be no pressure, easy wearing and taking off, covering the breasts and a bra top form. Therefore, a comfort bra top 
that covers the breasts and provides comfort with no wires was designed.

This study is significant in that it analyzed current bra wear and bra wear related needs of the new senior generation and extracted designs based on the findings. However, the spread of age and area was not wide but focused on the needs of the new senior generation in the metropolitan area, and there is a need for wider research on expanded areas.

\section{Acknowledgement}

"This research was supported by the MKE(The Ministry of Knowledge Economy), Korea, under the Technological Innovation Project (KEIT-10042080) supervised by the Korea Evaluation Institute of Industrial Technology"

\section{References}

'Aging society'. (2013). Naver encyclopedia. Retrieved April 26, 2013, from http://terms.naver.com/search.nhn?query $=\% \mathrm{EA} \% \mathrm{~B} 3 \% \mathrm{~A} 0 \%$ EB\%A0\%B9\%EC\%82\%AC\%ED\%9A\%8C

Attention-promising market in demographic change. (2012, November). KOTRA. Retrieved December 7, 2012, from http:// www.globalwindow.org/GW/global/trade/info/all-detail.html?\& $\mathrm{SCH} \_\mathrm{TYPE}=\mathrm{SCH} \_\mathrm{SJ} \& \mathrm{MENU} \_\mathrm{CD}=\mathrm{M} 10502 \& \mathrm{SCH}$ ARTICLE $\mathrm{SE}=\& \mathrm{SCH}$ TRADE_CD $=\& \mathrm{MODE}=\&$ ARTICLE ID $=2159434 \&$
UPPER_MENU_CD $=\mathrm{M} 10501 \& B B S \_I D=0 \& S C H \_V A L U E=\& S$ CH_AREA_CD $=\& M E N U \_S T E P=2 \& R E L \_A R E A \_C D=\&$ Page $=$ 7\&SCH_NATION_C

Cha, J. Y. (2008). Study on the silver generation's physical characteristics-considered underwear design. Unpublished master's thesis, Ewha Womens University, Seoul.

Choi, K. S. (1995). A study on the clothing behavior of middle-age women and old-age women. Unpublished master's thesis, Kongju National University, Kongju.

Kang, J. J. (2010). A research on online shopping and shopping behaviors of a new silver generation. Unpublished master's thesis, Ewha Womens University, Seoul.

Kim, G. B. (2011). A study on the elderly women's clothing purchasing behavior according to their lifestyle. Unpublished master's thesis, Sookmyung Women's University, Seoul.

Kim, J. S. (2006). A study on the spending behaviors, related to the cognitive age of the consumers in the elderly generation. Unpublished doctoral dissertation, Sookmyung Women's University, Seoul.

Lee, S. Y., \& Chun, J. S. (2012). Women's perceptions of physical deformation from aging and demand on postural correction wear. The Research Journal of the Costume Culture, 20(5), 725-735.

Park, W. (2003). Strategy for Sliver market of Japanese companies. Asia Management Institute p. 7.

(Received 23 May 2013; 1st Revised 31 May 2013; 2nd Revised 12 June 2013; Accepted 22 June 2013)

Copyright (C) The Society of Fashion and Textile Industry. 2013. This is an open access article distributed under the terms and conditions of the Creative Commons Attribution Non-Commercial license (http://creativecommons.org/licenses/by-nc/3.0/), which permits unrestricted non-commercial use, distribution, and reproduction in any medium, provided the original work is properly cited. 